WSRC-TR-2002-00396

Rev. 0

\title{
Residual Stress Testing of Outer 3013 Containers (U)
}

\author{
K. A. Dunn \\ Savannah River Technology Center \\ Strategic Materials Technology Department \\ Materials Technology Section
}

Publication Date: August, 2003

\author{
DOES NOT CONTAIN \\ UNCLASSIFIED CONTROLLED \\ NUCLEAR INFORMATION
}

ADC \&

Reviewing Official:

Date:

Patent Status

This internal management report is being transmitted

Without DOE patent clearance, and no further

Dissemination of or publication shall be made of a report without prior approval of the DOE-SR patent counsel.

\section{Westinghouse Savannah River Company Savannah River Site Aiken, SC 29808}

This document was prepared in connection with work done under Contract Nos. DEAC09-89SR18035 and DE AC09-96SR18500 with the U. S. Department of Energy 
This document was prepared in conjunction with work accomplished under Contract No. DE-AC09-96SR18500 with the U. S. Department of Energy.

\section{DISCLAIMER}

This report was prepared as an account of work sponsored by an agency of the United States Government. Neither the United States Government nor any agency thereof, nor any of their employees, makes any warranty, express or implied, or assumes any legal liability or responsibility for the accuracy, completeness, or usefulness of any information, apparatus, product or process disclosed, or represents that its use would not infringe privately owned rights. Reference herein to any specific commercial product, process or service by trade name, trademark, manufacturer, or otherwise does not necessarily constitute or imply its endorsement, recommendation, or favoring by the United States Government or any agency thereof. The views and opinions of authors expressed herein do not necessarily state or reflect those of the United States Government or any agency thereof.

This report has been reproduced directly from the best available copy.

Available for sale to the public, in paper, from: U.S. Department of Commerce, National Technical Information Service, 5285 Port Royal Road, Springfield, VA 22161, phone: (800) 553-6847, fax: (703) 605-6900

email: orders@ntis.fedworld.gov

online ordering: http://www.ntis.gov/help/index.asp

Available electronically at http://www.osti.gov/bridge

Available for a processing fee to U.S. Department of Energy and its contractors, in paper, from: U.S. Department of Energy, Office of Scientific and Technical Information, P.O. Box 62, Oak Ridge, TN 37831-0062,

phone: (865)576-8401,

fax: (865)576-5728

email: $\underline{\text { reports@ adonis.osti.gov }}$ 
WSRC-TR-2002-00396

Rev. 0

Report Title: Residual Stress Testing of Outer 3013 Containers (U)

\section{APPROVALS:}

K. A. Dunn

Date

Task Leader

P. S. Korinko

Date

Technical Reviewer

G. T. Chandler

Date

Manager Materials Application and Corrosion Technology Group

N. C. Iyer

Date

Manager, Materials Technology Section 
WSRC-TR-2002-00396

Rev. 0

\section{Table Of Contents}

Summary

Introduction 1

Description of Outer 3013 Container $\quad 2$

$\begin{array}{ll}\text { Experimental Test Setup } & 2\end{array}$

Analysis

$\begin{array}{ll}\text { Discussion } & 4\end{array}$

$\begin{array}{ll}\text { Conclusion } & 4\end{array}$

References $\quad 5$ 
WSRC-TR-2002-00396

Page 1 of 16

Rev. 0

\section{$\underline{\text { Residual Stress Testing of Outer } 3013 \text { Containers (U) }}$}

\section{$\underline{\text { Summary }}$}

A Gas Tungsten Arc Welded (GTAW) outer 3013 container and a laser welded outer 3013 container have been tested for residual stresses according to the American Society for Testing Materials (ASTM) Standard G-36-94 [1]. This ASTM standard describes a procedure for conducting stress-corrosion cracking tests in boiling magnesium chloride $\left(\mathrm{MgCl}_{2}\right)$ solution. Container sections in both the as-fabricated condition as well as the closure welded condition were evaluated. Significantly large residual stresses were observed in the bottom half of the as-fabricated container, a result of the base to can fabrication weld because through wall cracks were observed perpendicular to the weld. This observation indicates that regardless of the closure weld technique, sufficient residual stresses exist in the as-fabricated container to provide the stress necessary for stress corrosion cracking of the container, at the base fabrication weld. Additionally, sufficiently high residual stresses were observed in both the lid and the body of the GTAW as well as the laser closure welded containers. The stresses are oriented perpendicular to the closure weld in both the container lid and the container body. Although the boiling $\mathrm{MgCl}_{2}$ test is not a quantitative test, a comparison of the test results from the closure welds shows that there are noticeably more through wall cracks in the laser closure welded container than in the GTAW closure welded container.

\section{Introduction}

The DOE Complex is packaging plutonium $(\mathrm{Pu})$ containing materials for eventual storage at various sites in the complex. The $\mathrm{Pu}$ materials are packaged according to the DOE 3013 standard [2] which outlines general requirements relevant to the planned DOE activities to stabilize Pu materials, package them in 3013 containers, and place them in long-term storage until future facilities are available to convert these materials to other forms. To ensure these materials remain in a safe configuration throughout their storage life, the complex wide Integrated Surveillance Program (ISP) [3] developed a document that discusses the necessity of 3013 container surveillance. Successful, long-term surveillance requires the comparison of the characteristics of the actual stored systems against the baseline or pre-storage characteristics of those same systems and the information obtained from a lead surveillance program. Baseline characterization of the outer 3013 container can yield information to support future observations of packages in storage and a lead surveillance program for the outer 3013 container will ensure the safety of stored packages over their intended storage time.

The lead surveillance program for the outer 3013 container is being established at SRS to support DOE Complex issues. The outer 3013 container, fabricated of low carbon grade, 300 series stainless steel, is the specified barrier to the environment for the stored plutonium material. It is a robust container and age-related degradation is unlikely. However, two potential failure mechanisms of the 3013 container associated with moisture and impurities have been identified through the Materials Identification and 
Rev. 0

Surveillance (MIS) program [2,4]: 1) pressurization due to gas generation and 2) corrosion associated with impurities (specifically chlorides and fluorides) in the plutonium oxides. Corrosion degradation over the storage time is the primary focus of the outer 3013 container lead surveillance program. Surrogate plutonium packages will be assembled and placed in storage for future non-destructive and destructive examinations as part of this program. The surrogate materials will contain various concentrations of halides consistent with actual product.

As part of the surrogate plutonium packages, an inner container has been specially designed to incorporate an internal heating source to simulate the radioactive decay heat expected from the plutonium material. In addition, a mechanically induced flaw will be incorporated into the inner container to simulate a compromised package for lead surveillance information. This mechanically induced flaw will be positioned in a location that will be near a high stress region of the outer container, as determined from a boiling $\mathrm{MgCl}_{2}$ test. The boiling $\mathrm{MgCl}_{2}$ test is designed to provide an accelerated method of ranking the relative degree of stress corrosion cracking susceptibility for stainless steels and related alloys in aqueous chloride-containing environments. Stress-corrosion cracking refers to cracking caused by the simultaneous presence of a susceptible alloy, sustained tensile stress, and a particular environment [5]. The tensile residual stresses are present in the 3013 container from both the fabrication and closure weld processes. In the current study the $\mathrm{MgCl}_{2}$ provides the corrosive environment to help establish the susceptibility to SCC. This paper discusses the boiling $\mathrm{MgCl}_{2}$ tests conducted on the outer 3013 containers to determine their susceptibility to stress corrosion cracking.

\section{Description of Outer 3013 Container}

The DOE Standard 3013 [2] outlines general requirements relevant to the planned DOE activities to stabilize and package $\mathrm{Pu}$ materials in 3013 containers, and place them in long-term storage. The outer 3013 container has been qualified as the primary barrier to the environment during storage of the plutonium materials. The design and fabrication of the outer 3013 containers are consistent across the DOE complex, Figure 1, and they comply with approved engineering drawings [6, 7, 8, 9]. The outer 3013 container, fabricated of "enhanced strength" low carbon grade 316 (i.e., type 316L SS) stainless steel has an inner diameter of 4.68", outer diameter of 4.91" and a height of 9.84", without the lid. The placement of the lid with the can sidewall provides an interference fit and therefore creates a crevice due to the chamfer and weld geometry. Two types of closure welds for the outer 3013 container have been approved within the DOE complex, namely the laser beam weld (LBW) and the gas tungsten arc weld (GTAW).

\section{Experimental Test Setup}

Three outer 3013 containers, two closure welded and one not closure welded, were sectioned axially in half with an electrical discharge machine (EDM) at the center height for the boiling $\mathrm{MgCl}_{2}$ test, Figure 2. The EDM technique was selected because this method minimizes the amount of residual stress introduced to the can as a result of the sectioning process. The two closure welded containers consisted of one LBW and one 
Rev. 0

GTAW container. The containers were sectioned at the center height so that the residual stress state in the welded regions, both the fabrication weld and the closure weld, would remain as undisturbed as possible. Figure 3 shows the test setup of the $\mathrm{MgCl}_{2}$ corrosion tests. During the test, each half of the 3013 container, which served as the sample as well as the vessel containing the $\mathrm{MgCl}_{2}$ solution, was placed in a larger containment vessel to collect any $\mathrm{MgCl}_{2}$ solution that may leak through the 3013 container specimen. The nested containers were then placed on a hot plate. A water-cooled condenser and lid, made to fit snugly into the 3013 container specimen, were designed with a liquid trap and an insert for a thermometer. A solution of 25 weight percent solution of magnesium chloride was placed in the liquid trap per the ASTM standard. The approximately $45 \%$ $\mathrm{MgCl}_{2}$ test solution that boils at $155.0 \pm 1^{\circ} \mathrm{C}$, prepared according to the ASTM Standard, consisted of $600 \mathrm{~g}$ of $\mathrm{MgCl}_{2} \cdot 6 \mathrm{H}_{2} \mathrm{O}$ mixed with $15 \mathrm{~mL}$ water. Sufficient solution was prepared to ensure the tip of the thermometer was immersed into the solution during the test. Once the boiling temperature of the test solution was established at $155.0 \pm 1^{\circ} \mathrm{C}$, it was then maintained during the test by either adding additional $\mathrm{MgCl}_{2}$ crystals to the condenser, to raise the boiling temperature, or by adding water to the condenser, to lower the boiling temperature.

The container samples were tested for 48 hours, during which no $\mathrm{MgCl}_{2}$ solution leaked through the sample container to the outer containment vessel. After the 48 hour exposure, each sample container was emptied of the $\mathrm{MgCl}_{2}$ contents, allowed to cool to room temperature, rinsed with tap water, and then filled with tap water for observation. Within a minute of being filled with tap water, leaking on the outside of the container was observed, indicating through wall cracks. The water was removed and the containers were examined.

\section{$\underline{\text { Analysis }}$}

\section{Examination of the As-Fabricated Containers}

Through wall cracks were observed in the bottom half of the as-fabricated container after 48 hours of testing, Figure 4. Other cracks were observed on the interior of the container section that did not appear to propagate through the wall. Approximately five through wall cracks were visible and they ranged in length from 0.15 ” to 0.81 ” in. All of the cracks observed visually were perpendicular to the base-to-can fabrication weld. Metallographic examination of one crack showed that they appear to begin in the heat affected zone and grow into the base of the can, Figure 5. The cracks were typical of stress corrosion cracks with regions of branching along their length and some areas of cracking $90^{\circ}$ from the main crack. The location and orientation of the cracks are consistent with the residual stresses expected as a result of the base-to-container weld and indicate that the residual stress state is significant in the as-fabricated weld region.

\section{Examination of the GTAW Closure Weld}

Through wall cracks perpendicular to the GTAW closure weld and along the length of the container body were observed after 48 hours of testing, Figure 6 (a). Through thickness 
Rev. 0

radial cracks were also observed on the lid after 48 hours of testing, Figure 6 (b). Cracks on the inside of the container, as tested, are shown in Figure 6 (c) and (d). All of these cracks are consistent with the residual stresses expected as a result of the GTAW closure weld. A crack, perpendicular through the weld and then running parallel to the closure weld, was observed as shown in Figure 7 (a) and is imaged with dye penetrant testing as shown in Figure 7 (b). The external cracks in the lid and along the length of the container through the weld (Figure 6 (a) \& (b)) however were not able to be imaged with dye penetrant testing. This observation seems to indicate that, although the cracks penetrated through wall, the resulting crack width was insufficient to allow the dye penetrant to resolve the crack.

\section{Examination of Laser Beam Welds}

Through wall cracks perpendicular to the laser closure weld and along the length of the container body were observed after 48 hours of testing, Figure 8 (a). Through wall radial cracks were also observed on the lid after 48 hours of testing, Figure 8 (b). All of these cracks are consistent with the residual stresses expected as a result of the laser closure weld. Pits were also observed inside the container, Figure 8 (c). The pits may be chloride induced pits that are exacerbated by the high residual stresses developed during the closure weld. Dye penetrant testing of the exterior of the tested container showed that the cracks observed in both the lid and the body were indeed through wall cracks and ran continuously from the lid into the body, Figure 9.

\section{$\underline{\text { Discussion }}$}

The boiling $\mathrm{MgCl}_{2}$ test is designed to indicate the susceptibility of stainless steels and related alloys to stress corrosion cracking. It was used in this study to identify locations of high residual stresses associated with fabrication of the stainless steel container. The $\mathrm{MgCl} 2$ test is designed to provide a relative SCC susceptibility of the material properties and is not meant to be a quantitative test. In the current study the boiling $\mathrm{MgCl}_{2}$ test was conducted on each of the sample containers under similar test conditions. In addition, the container and lid material met the same specification throughout the tests while the weld technique varied. Therefore, the relative damage to each of the samples can be compared. Through wall cracks were evident in the as-fabricated container sample after 48 hours at $155^{\circ} \mathrm{C}$ as well as the closure welded regions of the outer 3013 container which indicates that residual stresses over $10 \mathrm{ksi}$ are present in every 3013 container regardless of the closure weld technique. The cracks observed in the as-fabricated container, however, were not as numerous as those observed in the closure welded sections. Cracks observed in the laser closure welded container were numerous and appeared to be more severe when compared to those observed in the GTAW closure welded container.

\section{Conclusion}

The 3013 container, a robust low carbon grade 300 series stainless steel can, is used for packaging $\mathrm{Pu}$ containing materials for eventual storage at various sites in the DOE 
Rev. 0

complex. Two viable degradation mechanisms for these packages have been identified: 1) pressurization due to gas generation and 2) corrosion associated with impurities (specifically chlorides and fluorides) in the plutonium oxides. However, procedures have been developed to reduce the potential for container degradation, such as removing moisture prior to packaging, and consequently age-related degradation is unlikely in the storage configuration. In the current study, ASTM standard G-36-94, an aggressive testing procedure using boiling $\mathrm{MgCl}_{2}$ solution, was used to reveal the relative stress corrosion cracking susceptibility of the 3013 containers. The test revealed the presence of significantly large residual stresses in the bottom half of the as-fabricated container, a result from the base to can fabrication weld. This observation indicates that regardless of the closure weld technique, sufficient residual stresses exist to provide the stress component necessary for stress corrosion cracking. Additionally, cracks were observed in both the lid and the body of the GTAW and the laser closure welded containers as a result of this test technique. The presence of cracks in both of the closure welded container samples tested indicates that significant residual stresses are inherent in the closure welding process regardless of the closure weld method.

\section{$\underline{\text { References }}$}

[1] Standard Practice for Evaluating Stress-Corrosion-Cracking Resistance of Metals and Alloys in a Boiling Magnesium Chloride Solution, ASTM Designation: G3694

[2] DOE Standard Stabilization, Packaging, and Storage of Plutonium Bearing Materials, DOE-STD-3013-2000, September 2000

[3] Integrated Surveillance Program in Support of Long-Term Storage of Plutonium Bearing Materials, Rev. 1, LA-UR-00-3246, March 2000

[4] Kolman, D.G., "A review of the potential environmentally assisted failure mechanisms of austenitic stainless steel storage containers housing stabilized radioactive compounds”, Corrosion Science 43 (2001) 99-125

[5] Materials Handbook, Volume 13, Corrosion, ASM International, Materials Park, $\mathrm{OH}$,

[6] Drawing M-PV-F-0017, PuSPS, Plutonium Stabilization and Packaging System, Assembly and Details, Outer Can PI No. V4003, Revised by: S. M. Barton, US DOE, SRS, 6/24/99

[7] Drawing M-PV-F-0011, PuSPS, Plutonium Stabilization and Packaging System, Manufacturing Notes for Can Production, Revised by: C. Dowdy, US DOE, SRS, 6/22/99 
WSRC-TR-2002-00396

Page 6 of 16

Rev. 0

[8] Drawing M-PV-F-0014, PuSPS, Plutonium Stabilization and Packaging System, Details Outer Storage Can Identification, Revised by: P. C. Moore, US DOE, SRS, $6 / 21 / 99$

[9] Procurement Specification M-SPP-F-00070, Procurement Specification for DOESTD-3013 Plutonium Stabilization and Packaging System Production CANs, 7/2/99 
WSRC-TR-2002-00396

Page 7 of 16

Rev. 0

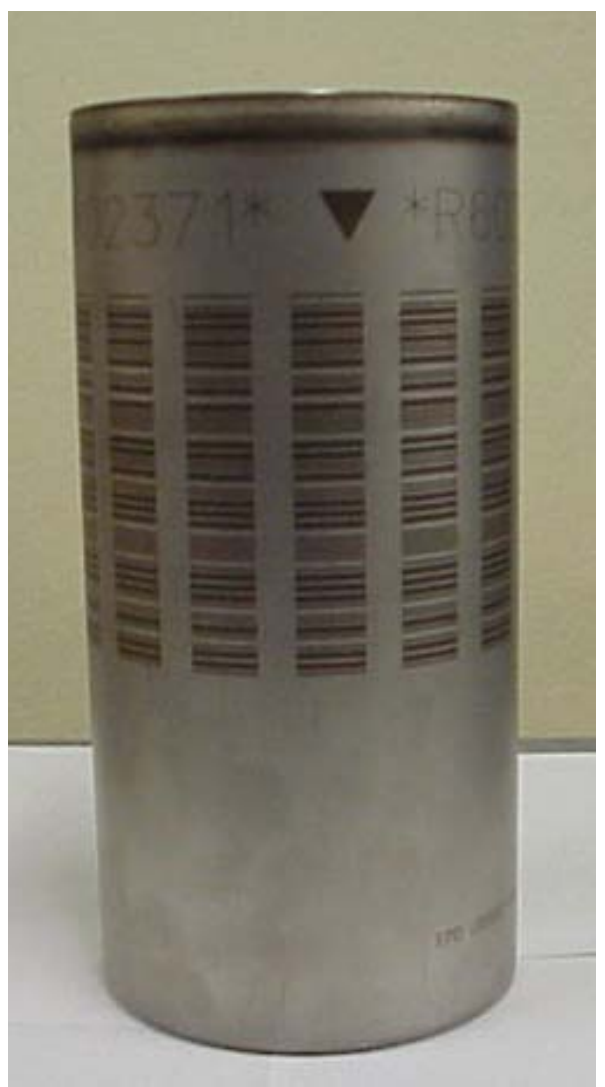

Figure 1. Outer 3013 Container. 
Rev. 0

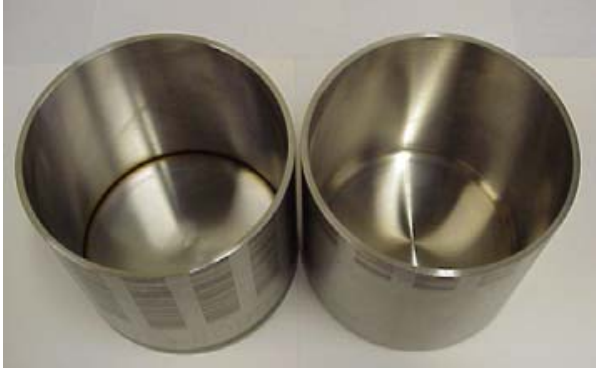

(a)

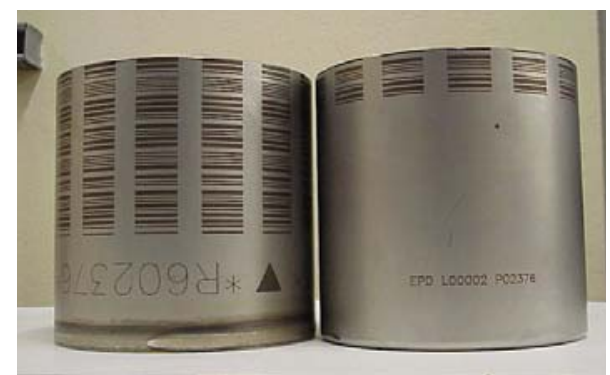

(c)

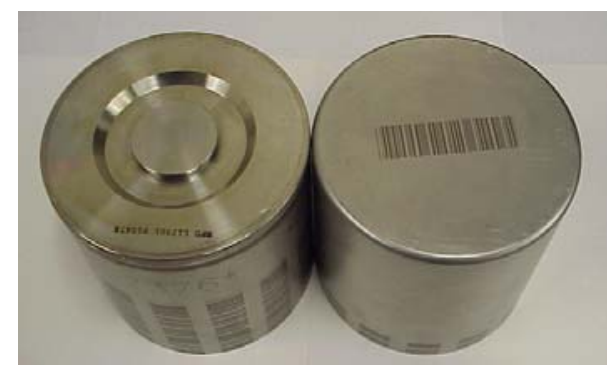

(b)

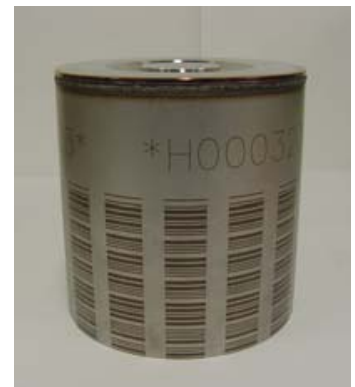

(d)

Figure 2. Sectioned Outer 3013 Containers For Testing (a) GTAW (b) GTAW (c) GTAW (d) LBW. 
WSRC-TR-2002-00396

Page 9 of 16

Rev. 0

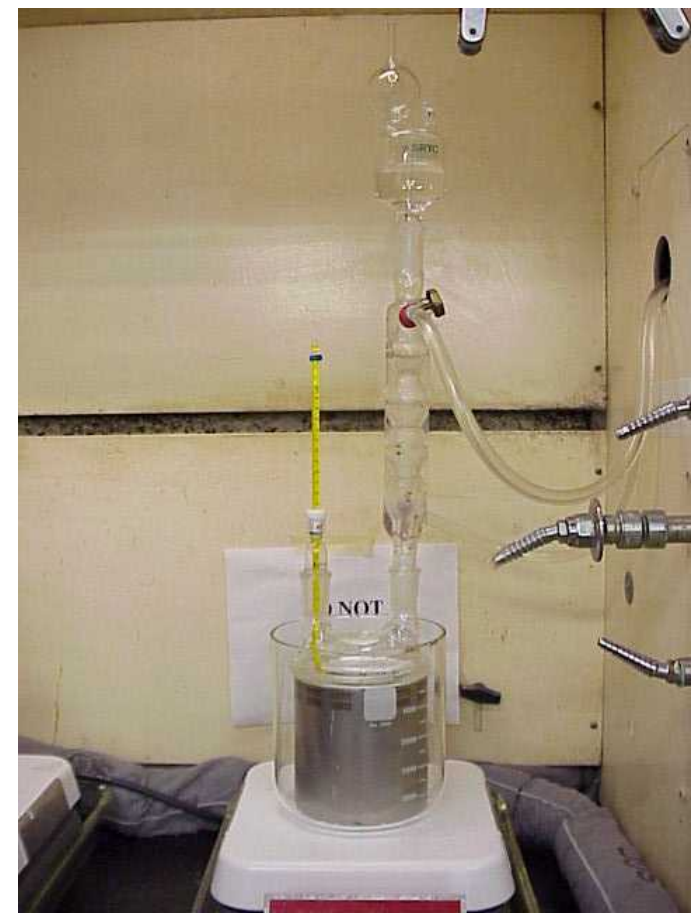

Figure 3. Test Setup For Boiling $\mathbf{M g C l}_{2}$ Test. 
Rev. 0

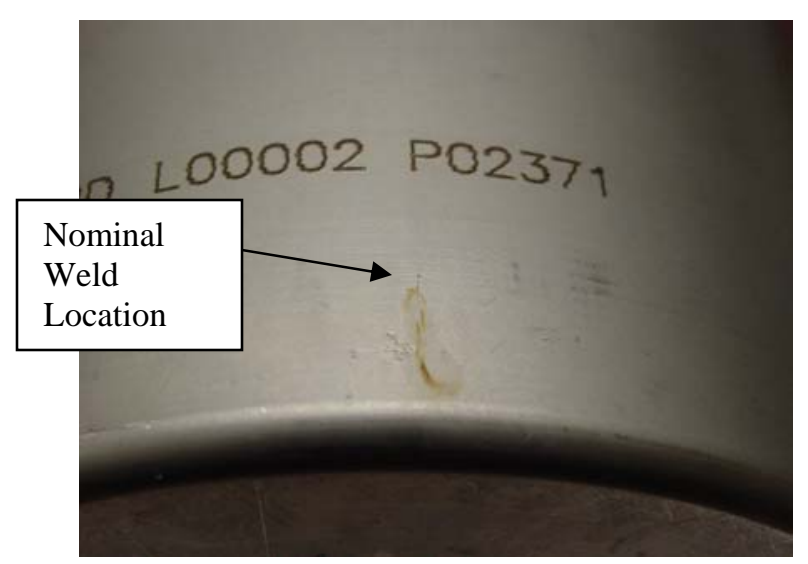

(a)

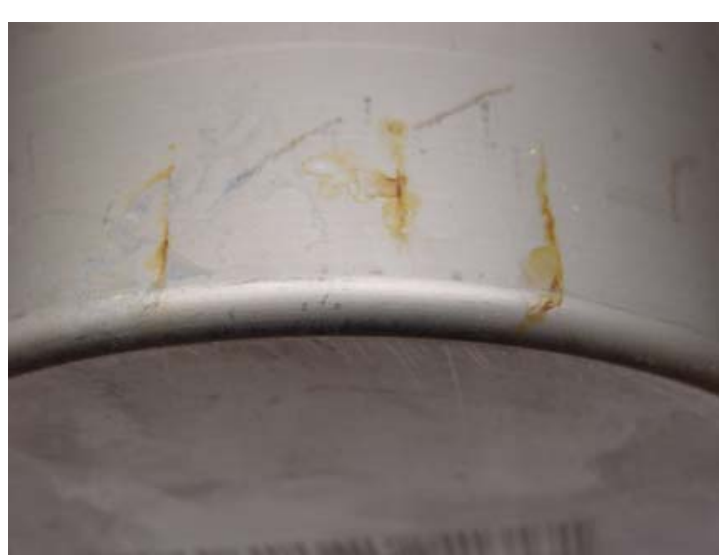

(b)

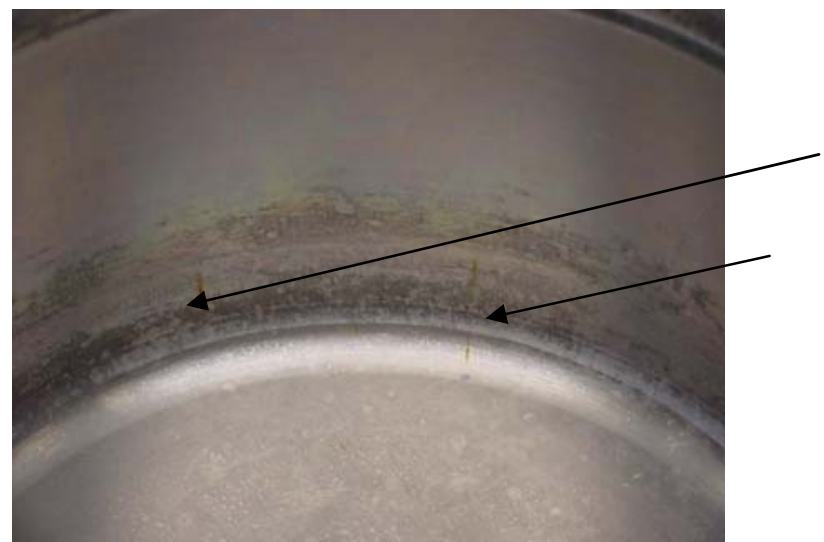

(c)

Figure 4. Bottom Half Of as-fabricated 3013 Container After Boiling $\mathrm{MgCl}_{2}$ Test. (a) Exterior of container through wall crack (b) Exterior of container through wall cracks (c) Interior of container cracks observed, arrows indicate cracks 
Rev. 0

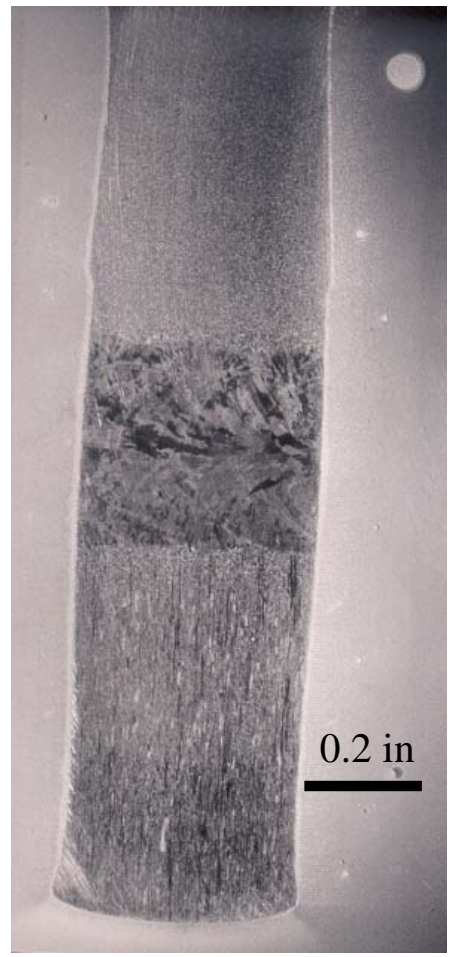

(a)

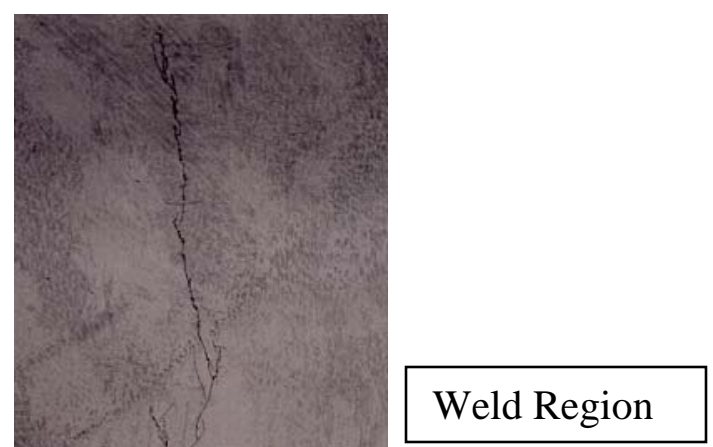

Base Forging

Figure 5. Metallographic cross section of through wall crack showing position of crack in relation to the can to base fabrication weld. (a) Overall macrograph showing base of can through fabrication weld and can body. (b) Stress corrosion crack associated with boiling $\mathrm{MgCl}_{2}$ test from sample shown in (a). Note the position of the crack, beginning in the weld region and propagating into the base of the can. Note also the crack branching. 
Rev. 0

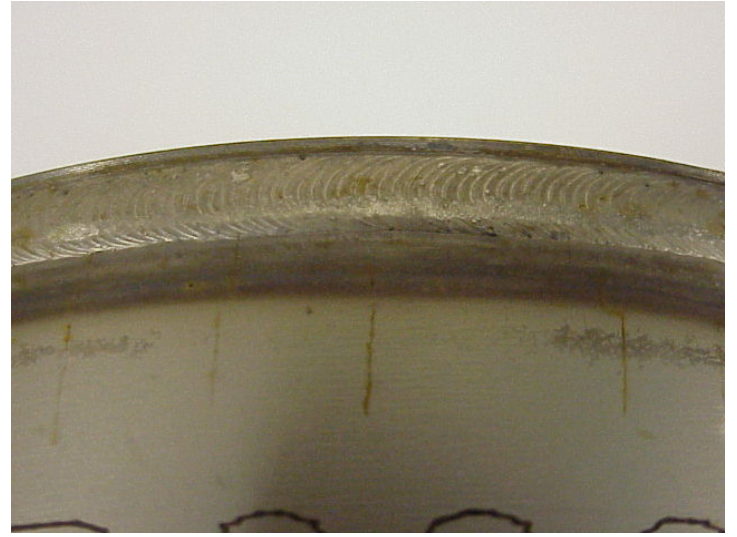

(a)

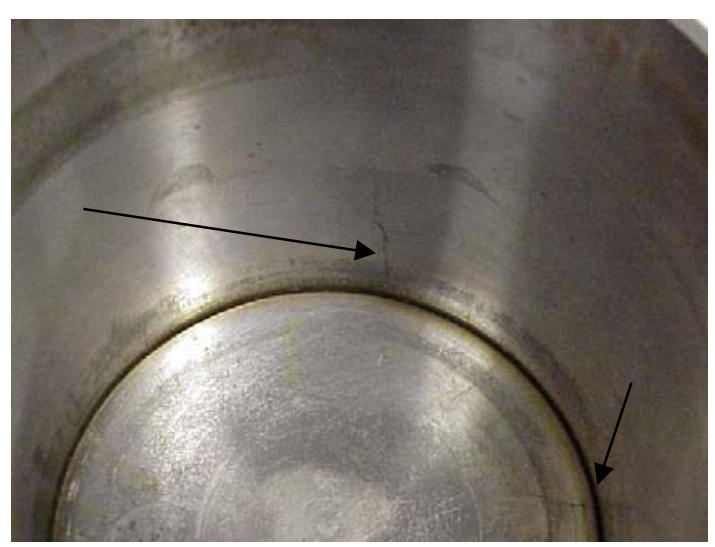

(c)

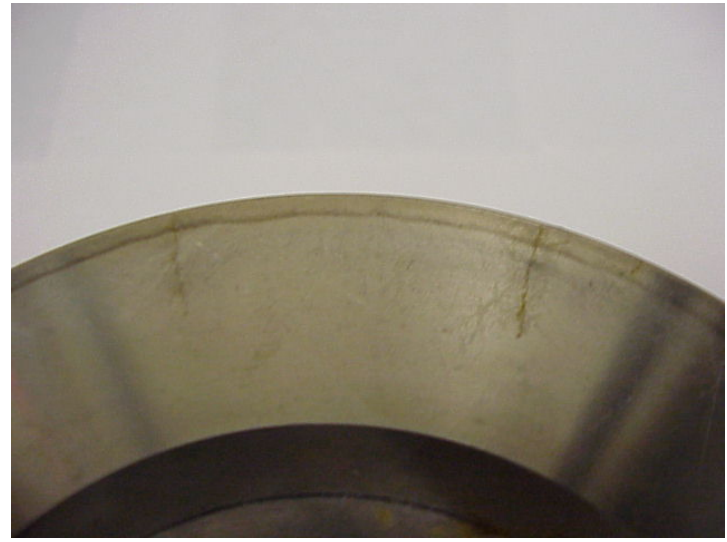

(b)

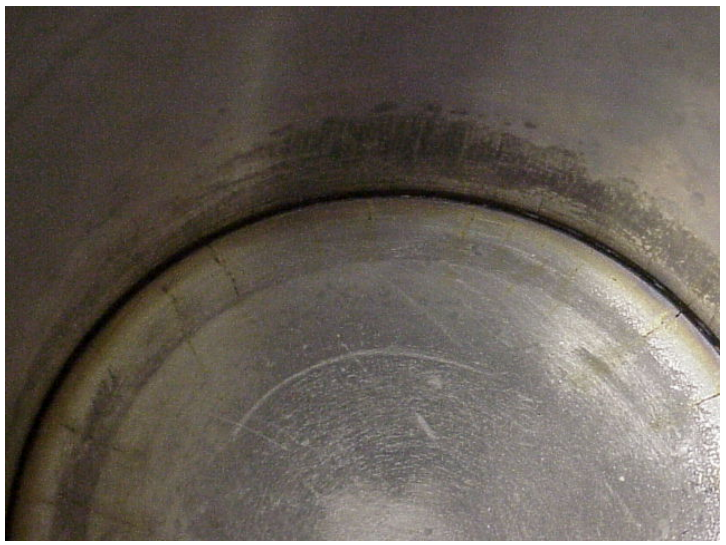

(d)

Figure 6. Top Half Of GTAW Closure Welded 3013 Container After Boiling $\mathbf{M g C l}_{2}$ Test. (a) Exterior of container with appearance of through wall cracks perpendicular to GTAW weld into body (b) Exterior of lid showing appearance of through wall cracks perpendicular to GTAW weld in lid (c) Interior of container cracks observed in body of container (d) Interior of container cracks observed in lid. 
Rev. 0

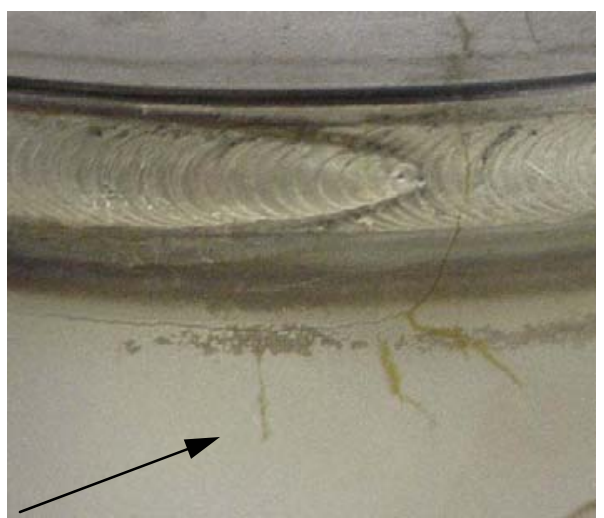

(a)

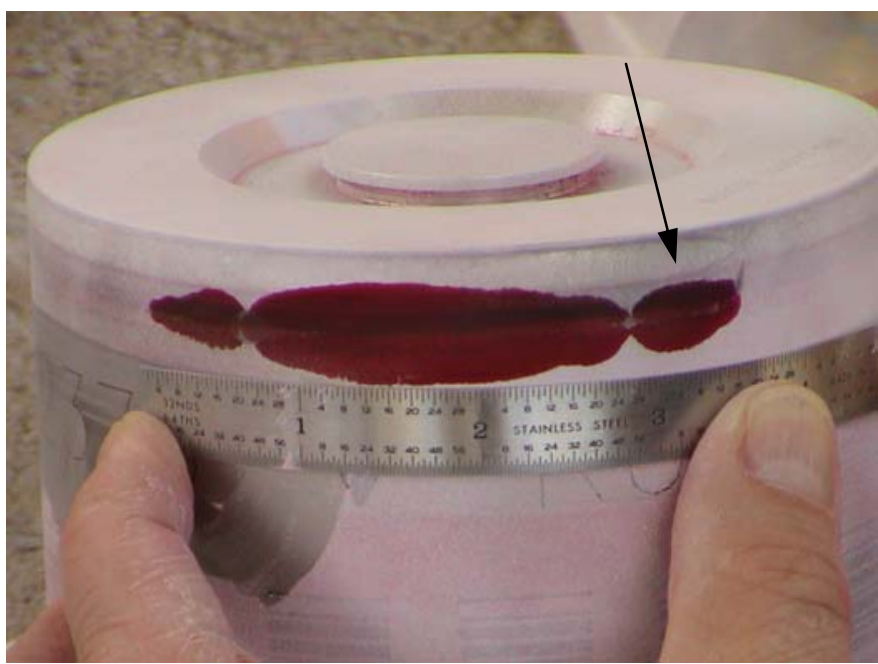

(b)

Figure 7. Top Half Of GTAW Closure Welded 3013 Container After Boiling $\mathbf{M g C l}_{2}$ Test. (a) Crack extending vertically through weld and running parallel to weld (b) Dye penetrant test showing crack parallel to closure weld. Note that none of the cracks, as shown in Figure 6 (a) and (b) are visible with dye penetrant testing. 
Rev. 0

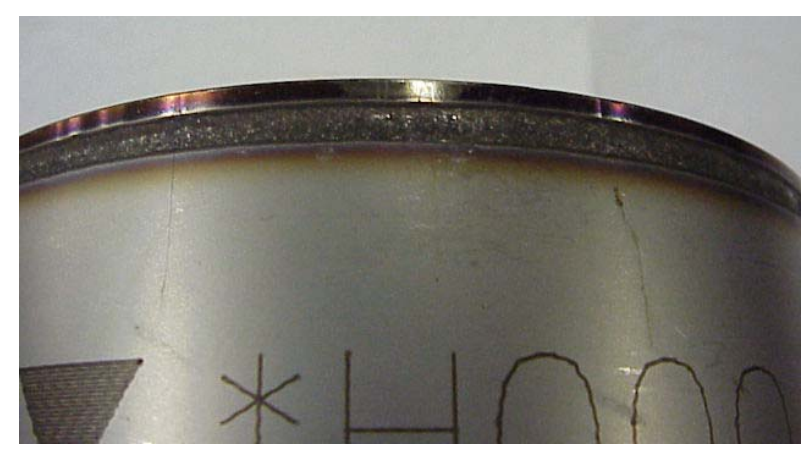

(a)

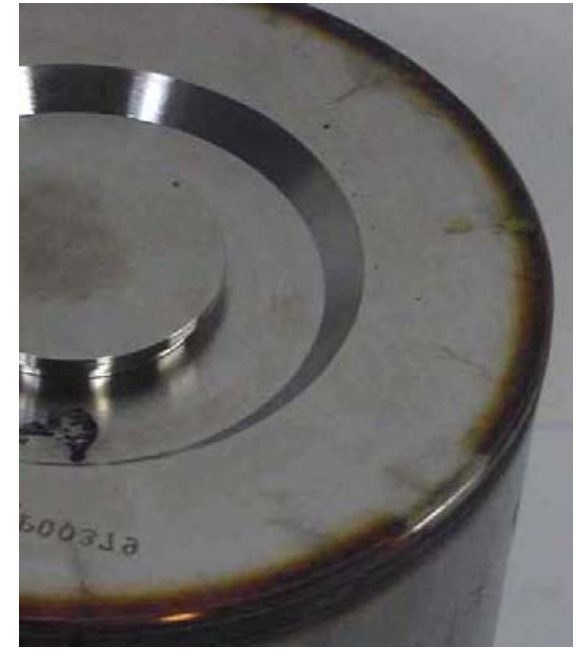

(b)

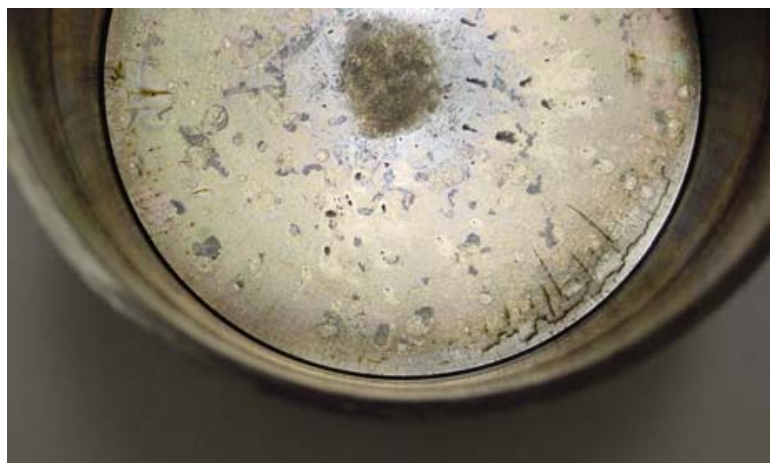

(c)

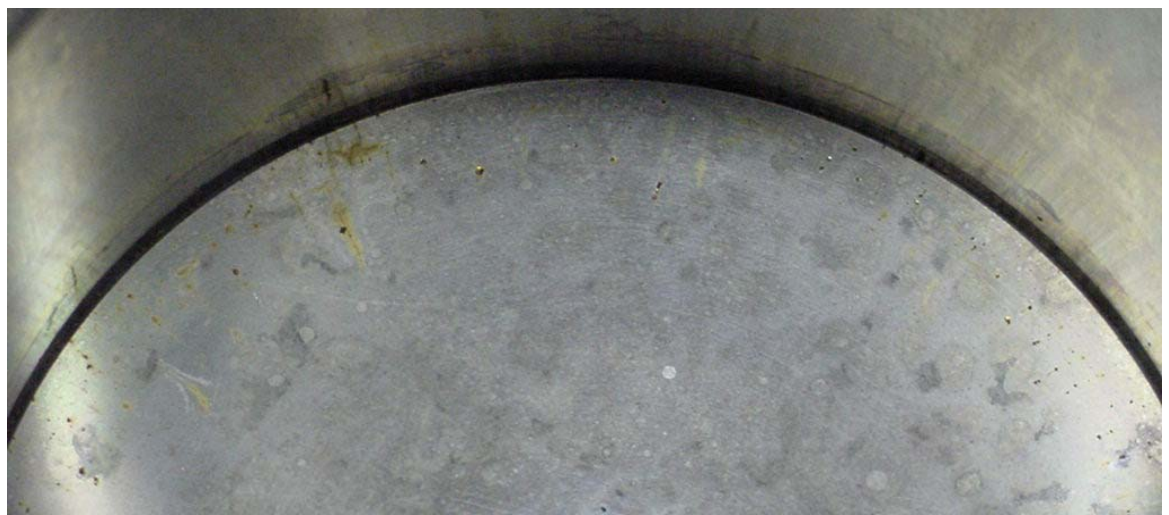

(d)

Figure 8. Top Half Of Laser Beam Closure Welded 3013 Container After Boiling $\mathrm{MgCl}_{2}$ Test. (a) Exterior of container through wall cracks perpendicular to laser weld into body (b) Exterior of lid through wall cracks perpendicular to laser weld in lid (c) Interior of container pitting and crack indications observed on lid of container (d) Interior of container pits and cracks observed in lid. 
WSRC-TR-2002-00396

Page 15 of 16

Rev. 0

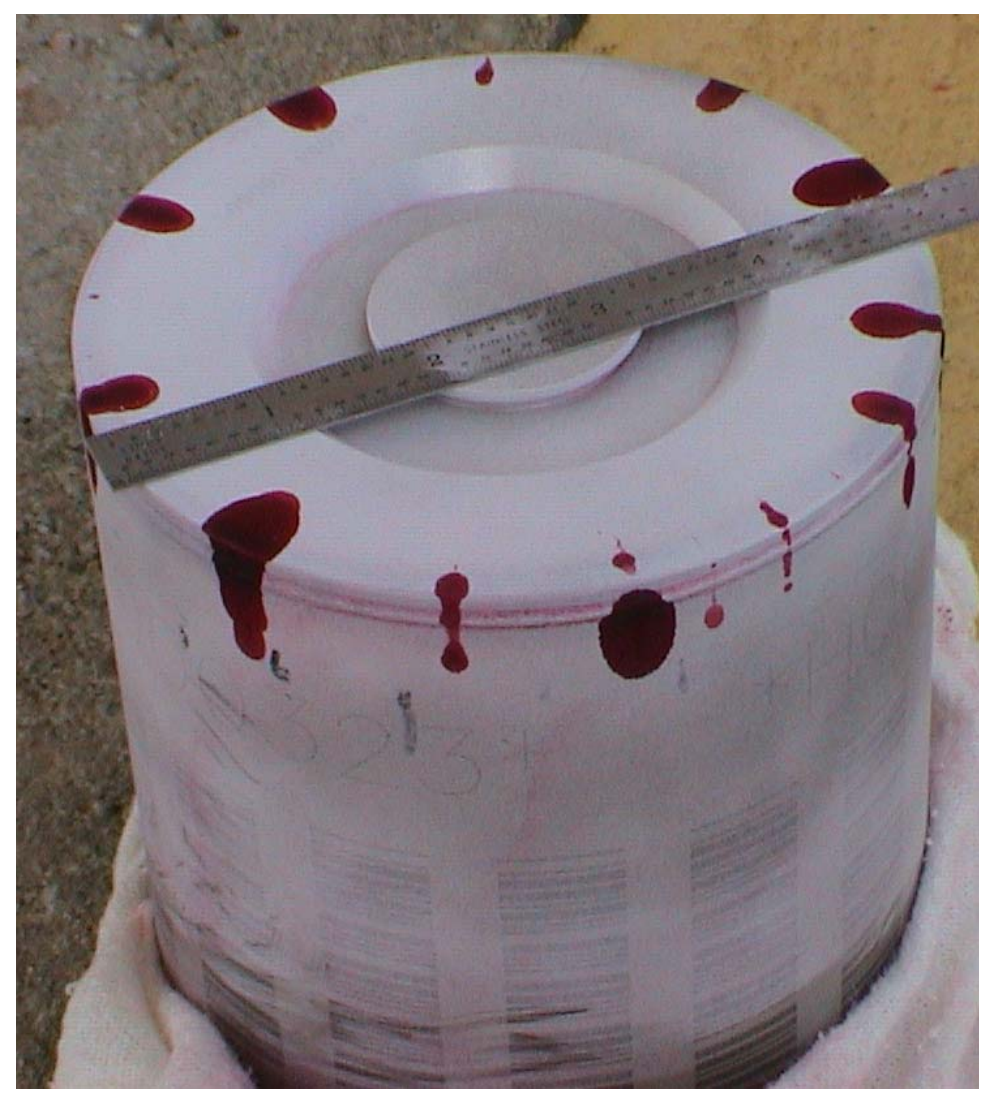

Figure 8. Dye Penetrant Test Of Top Half Of Laser Beam Closure Welded 3013 Container After Boiling $\mathrm{MgCl}_{2}$ Test. 